\title{
Konsep Pengembangan Ruang Wisata Berbasis Industri Kreatif
}

\author{
Suzanna Ratih Sari ${ }^{1}$, Edy Darmawan ${ }^{2}$, Dea Shamara ${ }^{3}$ \\ 1,2 Jurusan Arsitektur Fakultas Teknik, Universitas Diponegoro Semarang \\ Jl. Prof Sudarto SH Tembalang Semarang 50131
}

\begin{abstract}
ABSTRAK
Dusun Klipoh merupakan salah satu desa di sekitar Candi Borobudur yang dicanangkan sebagai desa wisata. Berdasarkan data yang ada, sekitar 60\% dari wisatawan Borobudur datang berkunjung ke desa Candirejo. Dengan semakin banyaknya jumlah wisatawan yang masuk ke kawasan desa wisata tersebut telah mempengaruhi berbagai kearifan budaya lokal di kalangan masyarakat sekitar candi Borobudur. Terjadilah perubahan-perubahan status sosial dan perubahan pandangan dalam masyarakat. Perubahan secara fisik desa pun juga terjadi, berubahnya tata guna dan status lahan-lahan di kawasan Borobudur bahkan ada beberapa rumah tinggal masyarakat Borobudur dengan gaya arsitektur lama yang masih dipertahankan meskipun beberapa bagian yang lain dari bangunan tersebut telah berubah sebagai akibat keterbatasan kemampuan dan pengetahuan masyarakat dalam merespon perubahan. Demikian juga dengan type desa yang muncul secara fisik mengalami modernisasi akibat pariwisata. Dalam perubahan sosial dan nilai-nilai dalam masyarakat dapat dilukiskan sebagai suatu sistem atau struktur yang memiliki elemen-elemen, ada elemen yang bertahan dan ada elemen yang berubah, namun tetap berada di dalam kondisi terintegrasi antar elemen. Mana elemen yang bertahan dan mana elemen yang berubah, semua akan ditampilkan sebagai pembahasan dalam penelitian. Penggalian potensi-potensi yang terkait dengan kearifan budaya lokal juga akan menjadi konsentrasi di dalam penelitian ini, walaupun perubahan-perubahan terjadi sebagai akibat dari berbagai pengaruh seiring dengan berjalannya waktu. Tentu saja tanda-tanda yang diyakini dan melandasi perilaku masyarakat selama ini dalam memberikan respon, persepsi, apresiasi, perilaku dan kreativitasnya berkaitan dengan aspek-aspek arsitektural dan perubahannya. Model-model pendekatan arsitektur akan lebih ditekankan sebagai metode untuk memecahkan permasalahan-permasalahan ruang wisata di area penelitian dan mapping bahavior akan digunakan untuk mengetahui pola pergerakan masyarakat pengrajin dan wisatawan yang akan dijadikan sebagai landasan dalam penyediaan ruang-ruang wisata. Adapun luaran penelitian adalah konsep pengembangan ruangruang wisata yang nyaman bagi pengrajin dan wisatawan.
\end{abstract}

Kata kunci: konsep pengembangan, ruang wisata, industri kreatif

\section{LATAR BELAKANG}

Pariwisata merupakan salah satu sektor yang dapat memberikan manfaat khususnya dalam meningkatkan kesejahteraan masyarakat karena pariwisata memiliki keterkaitan lintas sektor. Berkembangnya kegiatan pariwisata akan menggerakkan berlapis-lapis mata rantai usaha yang terkait di dalamnya sehingga akan menciptakan efek ekonomi multi ganda yang sangat berarti bagi masyarakat dan semua pihak yang terkait dalam mata rantai usaha kepariwisataan. Namun pada kenyataannya selama ini, kegiatan pariwisata belum memberikan dampak yang optimal kepada masyarakat. Masih banyak masyarakat miskin di sekitar objek wisata karena manfaat dari kegiatan pariwisata belum mereka dapatkan. Seperti halnya yang terjadi di salah satu desa wisata di Borobudur yakni Desa Karanganyar yang didalamnya terdapat dusun penghasil gerabah tradisional yakni dusun Klipoh. Dusun ini adalah dusun yang cukup unik, karena sebagian besar masyarakatnya adalah pengrajin gerabah tradisional secara turun temurun dan merupakan mata pencaharian pokok, disamping bertani. Biasanya, masyarakat Klipoh membuat gerabah tradisional di rumah-rumah mereka. Mereka biasanya menggunakan space atau ruang untuk membuat gerabah di halaman rumah dan menerima tamu.

Semenjak dusun Klipoh mulai ditetapkan sebagai desa wisata, masyarakat pengrajin gerabah 
mulai harus berbenah khususnya untuk mengakomodasi para wisatawan yang berkunjung ke dusun mereka. Dengan segala keterbatasan pengetahuan masyarakat tentang penyediaan ruang wisata,mulailah bermunculan ruang-ruang wisata di dusun Klipoh. Namun demikian banyak ruang-ruang wisata yang hingga saat ini tidak dapat digunakan karena permasalahannya adalah bahwa ruang-ruang wisata tersebut tidak didasarkan pada kebutuhan aktivitas wisatawan tetapi masyarakat lebih melihat dan meniru ruang-ruang wisata yang terdapat di desa wisata Candirejo. Seperti contoh: Ruang showroom yang terdapat di rumah salah satu warga dusun Klipoh. Keberadaan ruang showroom tersebut dibuat seadanya dengan memanfaatkan ruang yang ada di dalam rumah maka yang terjadi saat ini adalah showroom tidak dapat digunakan dan berganti fungsi menjadi gudang gerabah atau ruang tamu.

Dari permasalahan-permasalahan ruang wisata yang sedianya dibuat untuk memberikan kenyamanan bagi wisatawan untuk beraktivitas tetapi pada kenyataan di lapangan banyak menimbulkan permasalahan karena harus berinteraksi dengan para pengrajin, maka dalam penelitian ini akan diteliti tentang konsep-konsep ruang wisata yang berbasis pada industri kreatif yakni gerabah yang tepat, layak dan nyaman untuk wisatawan dan pengrajin. Ruang-ruang wisata tersebut nantinya akan disosialisasikan kepada masyarakat dan diimplementasikan pada rumahrumah pengrajin sehingga dapat memberikan manfaat yang optimal bagi masyarakat.Penelitian ini juga ditujukan untuk memberikan solusi kepada masyarakat tentang pengelolaan ruang yang mereka miliki sebagai ruang wisata yang nyaman bagi wisatawan dan pengrajin sendiri.

\section{KAJIAN LITERATUR}

Masyarakat disekitar objek wisata merupakan salah satu aspek yang harus diperhitungkan eksistensi dan perannya baik dalam proses penyediaan ruang-ruang wisata itu sendiri maupun konsekuensi-konsekuensi terhadap peningkatan kemakmuran dan kesejahteraannya. Kegiatan pengembangan desa wisata khususnya desa wisata dengan industri kreatif sebagai keunikannya merupakan pengejawantahan dari konsep pariwisata berbasis ekonomi kreatif yang mengandung arti bahwa masyarakat desa memperoleh sebesar-besarnya dari kegiatan pariwisata yang didasarkan pada industri kreatif yang mereka kerjakan saat ini.

Keterlibatan masyarakat dalam proses penyediaan ruang-ruang wisata dengan memanfaatkan kegiatan industri yang mereka miliki menjadi penting karena mereka adalah subjek dalam pelaksanaan desa wisata berbasis industri kreatif. Pariwisata berbasis industri kreatif memberikan peluang yang lebih besar bagi partisipasi komunitas lokal untuk melibatkan diri di dalam proses pengambilan keputusan dan menikmati keuntungan perkembangan industri pariwisata. (Aneka, 2008).

Masyarakat desa pada dasarnya masih mengalami kesulitan dalam mengelola jenis usaha wisata yang baru dikenalnya bahkan untuk memfasilitasi wisatawan sekalipun. Masyarakat dalam hal ini juga dituntut menyediakan dan mengelola lahan untuk kegiatan pariwisata. Masyarakat yang terbiasa dengan kehidupan agraris tidak dapat begitu saja berperan sebagai masyarakat penyedia jasa wisata, dikarenakan kedua bidang tersebut memiliki karakteristik yang jauh berbeda

Sebagai suatu bentuk adaptasi sosial, kelompok-kelompok masyarakat di kawasan pedesaan baik secara individual maupun kelompok merupakan elemen-elemen struktur sosial yang akan berinteraksi secara fungsional terhadap tatanan ruang desa yang ada disekitarnya sebagai wujud dari mekanisme kehidupan dalam mempertahankan eksistensinya. Hasil ataupun media interaksi sosial tersebut terwujud dalam bentuk sistem nilai dan simbol-simbol yang berdimensi ruang dan waktu, dalam hal ini terbentuklah kebiasaan-kebiasaan atau tradisi-tradisi dalam wujud sistem perilaku, artefak dan arsitektur. Karena itu antara sistem perilaku, artefak (peralatan) dan karya arsitektur (aspek simbolik keruangan) terjalin kesatuan pengertian yang tidak dapat saling dilepaskan satu dengan lainnya (Nurhadi 1985)

Dari model adaptasi lingkungan Lawton dan Nahemow (1973) memberikan beberapa pemahaman tentang sikap dan perilaku. Sikap dan perilaku adaptasi yang positif terjadi apabila antara kompetensi dan tekanan lingkungan berada pada perbandingan tertentu. Pada tingkatan ini ditemukan tingkat kenyamanan yang paling baik dan tingkat performansi yang paling optimal. Apabila terjadi tekanan lingkungan lemah sedangkan kompetensi tinggi atau sebaliknya, maka akan menimbulkan sikap toleran. Pada tingkat di mana tekanan lingkungan sangat lemah dan kompetensi meningkat tajam, atau sebaliknya tekanan lingkungan meningkat tajam sedang kompetensi melemah, maka akan menimbulkan sikap yang negatif dan kesalahan perilaku adaptasi.

Sikap adaptasi yang disampaikan Lawton dan Nahemow diatas merupakan gambaran yang cukup jelas bahwa manusia melakukan proses adaptasi ketika ada tekanan atau pengaruh dari luar. Seperti halnya yang terjadi di dalam penelitian tentang konsolidasi ruang desa wisata ini. Pada penelitian ini, respon masyarakat terhadap faktor pengaruh atau tekanan yang muncul dari pariwisata telah mengarahkan masyarakat untuk melakukan adaptasi baik sosial maupun keruangan. Ruangruang yang tercipta mempunyai arti dan nilai yang plural dan berbeda, tergantung tingkat apresiasi 
dan kognisi individu-individu yang menggunakan ruang tersebut.

Proses pemikiran masyarakat tersebut didasari aspek norma, kultur, psikologi yang berbeda seperti yang diungkapkan (Rapoport, 1996). Dalam konteks keterkaitan perilaku dan lingkungannya, keduanya akan mempengaruhi respons individu terhadap stimuli lingkungan yang muncul.

\section{METODE PENELITIAN}

Metode penelitian yang digunakan untuk mencapai tujuan penelitian adalah metode penelitian studi kasus. Penelitian studi kasus merupakan metode penelitian yang menggunakan berbagai sumber data yang digunakan untuk meneliti, menguraikan, dan menjelaskan secara komprehensif berbagai aspek individu, kelompok, suatu program, organisasi atau peristiwa secara sistematis (Kriyantono, 2006). Hasil akhir metode ini adalah deskripsi detail dari topik yang diteliti (deskriptif).

Observasi atau pengamatan dimaksudkan membuat catatan dari seluruh keadaan dan kegiatan yang diamati, utamanya hal-hal yang berlaku umum bagi masyarakat atau kelompok sasaran serta kondisi lingkungan yang diamati. Wawancara dilakukan dengan dua cara yaitu wawancara melalui wawancara bebas mendalam terbuka (indepth interview) dan wawancara berstruktur tertutup. Wawancara bebas mendalam khususnya ditujukan kepada para informan pangkal dan informan kunci (key informant). Informan pangkal adalah orang yang dipandang mampu memberikan informasi secara umum dan mampu menunjukkan orang lain (informan kunci) yang dapat memberi informasi yang lebih mendalam, misalnya Camat, dan perangkat desa, atau tokoh masyarakat. Sedangkan informan kunci adalah orang-orang yang dapat memberikan jawaban atau informasi secara komprehensif serta memberi apresiasi atas pertanyaan-pertanyaan yang berkaitan dengan permasalahan pokok penelitian, dalam hal ini mengenai seluk beluk masalah arsitektur dan keruangan, berikut perubahannya dari waktu-kewaktu.

Data-data yang diperoleh baik dari hasil pengamatan dan wawancara akan diolah, diklasifikasikan, dikaitkan dengan sumber pustaka yang relevan, serta diimplementasikan sebagai pandangan-pandangan, sistem pengetahuan dan latar belakang yang mendasari tindakan atau perilaku manusia dalam pengambilan keputusan, memberi makna terhadap sesuatu dan berapresiasi, khususnya menyangkut perilaku yang berkenaan dengan aspek arsitektural dan keruangan.

\section{HASIL DAN PEMBAHASAN}

\section{Gambaran Lokasi Penelitian}

Dusun Banjaran 1 ini pada awalnya bernama Klipoh. Klipoh adalah asal kata dari Nyai Kalipah, Kali (sungai Krinjing) dan Poh (desa). Nyai Kalipah merupakan orang pertama kali menghuni dusun pinggir sungai Krinjing. Jadi Klipoh berarti desa di pinggir sungai. Dusun Klipoh memiliki pemandangan alam yang menawan diapit Pegunungan Menoreh dan Sumbing. Begitu juga pemandangan matahari terbit yang menakjubkan diantara Gunung Merapi dan Merbabu.

Desa wisata Klipoh adalah desa yang sebagian besar masyarakatnya adalah pengrajin grabah. Grabah merupakan tradisi turun menurun seperti yang tergambar dalam relief di Candi Borobudur. Pembuatan grabah diawali dengan lengkap Legenda Nyonyah Kundi yang makamnya terdapat di dusun Ngadiwinatan I (Dusun Nggunden). Kundi merupakan sebutan untuk pengrajin gerabah. Dusun tempat para Kundi disebut Pakunden yang akhirnya disebut Nggunden. Para Kundi tersebut pada masa pembangunan Borobudur berlaku sebagai logistic yang diangkut dengan gerabah. Tradisi pembuatan gerabah ini sekarang bergeser ke Dusun Klipoh (Banjaran I). Gerabah dibuat hanya oleh kaum wanita, sedangkan pembakaran dan pemasaran gerabah dilakukan oleh kaum pria. Gerabah yang dibuat masih merupakan gerabah tradisional yang digunakan untuk perabot dan keperluan sehari-hari seperti coek, kuali, wajan, pot bunga, kendi dan blengker.

\section{ANALISIS}

Dalam konteks Arsitektur, fenomena seperti diatas sekilas menunjukkan adanya kegiatan pembuatan gerabah yang dilakukan masyarakat dan ruang produksi gerabah sebagai tempat yang digunakan untuk memproses gerabah. Dari keduanya kemudian berkembang dengan adanya wisatawan yang datang berkunjung ke lokasi pembuatan gerabah sehingga secara tidak langsung juga menuntut untuk penyediaan ruang di rumah para pengrajin gerabah.Rumah-rumah yang ada di desa wisata Klipoh, kebanyakan tipikal rumah di Desa Klipoh masih menggunakan konstruksi sederhana yakni dengan menggunakan struktur kayu dengan rangka atap menggunakan bambu. Lantai rumah masih menggunakan tanah dan pondasi batu kali masih terlihat. Kondisi rumah masih menggambarkan nuansa alami zaman nenek moyang. Tipe rumah merupakan tipe kampong tanpa adanya pendopo. Soko guru dalam rumah masih dipertahankan dengan umpak yang tinggi.

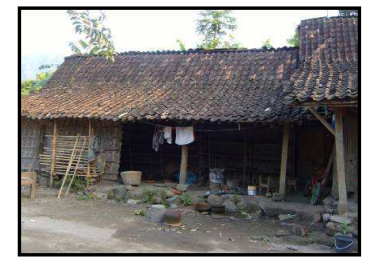

Gb. 1 Bentuk Rumah Tradisonal Desa Wisata Klipoh 
Pola tatanan perumahan yang ada bentuknya mengelompok berdasarkan hubungan kekeluargaan yang berlaku di situ. Orientasi perumahan disana cenderung terpusat pada sumur. Sumur sendiri oleh masyarakat Klipoh digunakan sebagai sumber mata air dan diletakkan di tengahtengah lingkungan permukiman mereka. Adapun makna perletakan tersebut adalah agar masyarakat dapat menggunakan sumber air secara bersamasama. Di desa wisata Klipoh sumber air relative cukup sulit sehingga masyarakat Klipoh sangat menghargai sekali keberadaan air. Terlebih lagi dari tingkat ekonomi masyarakat, kebanyakan dari warga yang bertempat tinggal dalam satu kawasan ini banyak yang tidak mampu membangun sendiri sumurnya, melainkan menggantungkan pada orang yang mampu membangun sumur.

Biasanya perumahan Jawa terutama di daerah Kedu Bagelen seperti di Borobudur ini sumur diletakkan di bagian depan seperti yang dapat ditemui di beberapa kampung atau desa di sekitar Borobudur. Hanya di desa wisata Klipoh yang memiliki bentuk permukiman yang justru menjadikan sumur sebagai pusat orientasi. Rumahrumah di desa Klipoh yang mengitari sumur biasanya adalah rumah-rumah milik kerabat dekat. Mereka memiliki hubungan kekerabatan yang sangat kuat sehingga terkesan permukiman yang ekslusif untuk satu pohon keluarga. Demikian juga untuk kelompok keluarga yang lain, mereka juga akan membentuk satu komunitas tersendiri dengan sumur di tengah sebagai orientasinya.

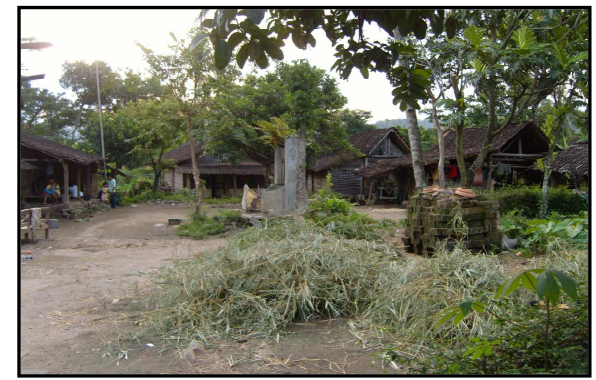

Gb. 2. Rumah-rumah yang mengelilingi sebuah sumur sebagai pusat orientasi di Desa Klipoh

Rumah-rumah yang mengelilingi sumur pada gambar di atas umumnya berbentuk rumah tipe kampung atau sering juga disebut tipe pelana yang banyak dijumpai di pedesaan di Jawa, yang dilengakapi dengan tutup keong pada kanan dan kiri bagian atas rumah. Sebagai sebuah kompleks dengan sebuah sumur di tengahnya, kompleks ini memiliki sebuah tempat pembakaran gerabah yang disebut kampung, untuk digunakan bersama-sama sebagai kelompok masyarakat pengrajin gerabah. Hal ini sekaligus juga menunjukkan masih berlakunya pranata gotong royong untuk membina kebersamaan yang memang sangat diperlukan bagi masyarakat tradisional di pedesaan karena sering merasa rentan terhadap lingkungan alam maupun sosialnya, maka selalu mengedepankan kehidupan gotong royong, meliputi pula dalam pola pemukimannya.

Namun demikian, seiring dengan perkembangan jaman dan banyaknya pengaruh yang masuk, bentuk perumahan seperti itu beberapa sudah berubah. Ada yang terpotong oleh jalan sehingga beberapa keluarga terpisah dan hanya beberapa keluarga yang masih mempertahankan pola tatanan perumahannya. Kondisi demikian dilakukan sebagai salah satu upaya masyarakat untuk meningkatkan daya tarik bagi wisatawan.

Terkait dengan proses produksi gerabah yang dilakukan masyarakat dan penentuan ruang-ruang wisata di dalam area perumahan masyarakat pengrajin gerabah, maka berikut adalah deskripsi tentang proses pembuatan gerabah dan ruangruang yang dibutuhkan untuk mengakomodir kegiatan pembuatan gerabah tersebut.

Adapun kebutuhan runag produksi yang disediakan masyarakat untuk memfasilitasi proses produksi di dalam rumah tinggal mereka adalah :

- Tempat tinggal

Masyarakat Klipoh pada umumnya menggunakan rumah utamanya sebagai tempat tinggal dan untuk melakukan kegiatan membuat gerabah. Kedua kelompok pengrajin memiliki tujuan yang sama terhadap rumah mereka. Ruang utama biasanya mereka gunakan sebagai tempat untuk melakukan kegiatan rutin sehari-hari seperti tinggal, tidur, makan, kumpul keluarga, menerima tamu. Sedangkan untuk kegiatan produksi gerabah biasanya mereka menggunakan teras depan atau belakang rumah. Ukuran yang dijadikan sebagai tempat tinggal biasanya bervariasi antar rumah yang satu dengan rumah yang lain tergantung dari kebutuhan dan kemampuan masing-masing keluarga.

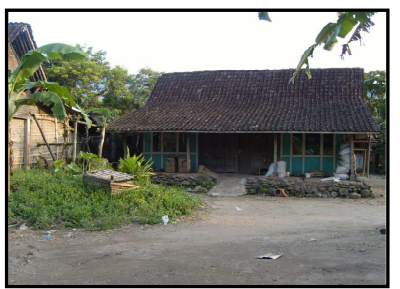

Gb.7 Contoh rumah tinggal sekaligus memiliki ruang untuk pembuatan gerabah

- Ruang pembuatan gerabah adalah ruang atau space yang digunakan untuk membuat dan memproduksi gerabah. Di ruang ini masyarakat melakukan aktivitasnya dari persiapan, proses pembuatan dan finishing dilakukan secara berurutan dan karena lokasinya terpisah dari ruang utama maka masyarakat dapat leluasa untuk melakukan aktivitasnya tanpa mengganggu aktivitas utamanya. Luas ruangan efektif yang dibutuhkan untuk orang membuat 
gerabah ini adalah $1.5 \mathrm{~m} \times 1.5 \mathrm{~m}$ (dengan mesin khusus) ada yang $1 \mathrm{~m} \times 1 \mathrm{~m}$ untuk mesin putar yang tradisional. Seperti yang terlihat dalam gambar di bawah ini:

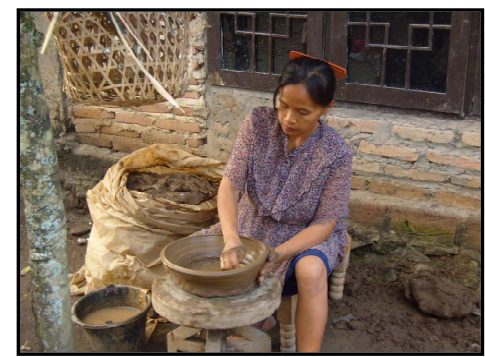

Gb. 8 Seorang pengrajin gerabah yang bekerja di teras halaman rumahnya

- Tempat pembakaran (disebut masyarakat sebagai "kampung") adalah tempat yang digunakan untuk membakar gerabah secara tradisional. Mereka tidak menggunakan oven karena mereka tidak terbiasa, mereka hanya menggunakan jerami-jerami kering yang biasa mereka beli dari masyarakat yang lain. Ada satu orang anggota masyarakat yang memiliki oven tetapi karena membutuhkan kayu yang cukup banyak dan menurut mereka kurang efektif sehingga untuk sementara oven tidak digunakan. Mereka kembali ke teknologi yang tradisional karena dianggap lebih efisien dan lebih efektif.

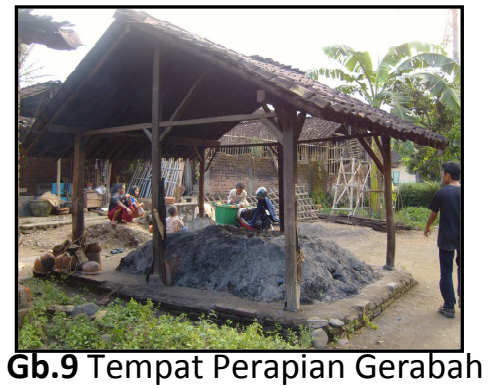

- Gudang jerami, adalah tempat untuk penyimpanan dan penimbunan jerami yang disediakan untuk pembakaran gerabah. Gudang jerami ini oleh masyarakt dibuat dengan ukuran sekitar $2 \mathrm{~m} \times 3 \mathrm{~m}$ khusus untuk menempatkan jerami-jerami yang lain dibeli masyarakat.

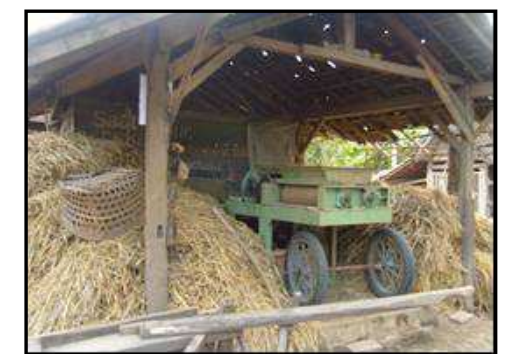

Gb. 10 Tempat Penyimpanan Jerami
- Ruang pamer, adalah ruang yang digunakan untuk mendisplaykan hasil gerabah yang sudah siap jual. Tidak semua masyarakat memiliki ruang pamer ini, bahkan atas kesepakatan bersama untuk saat ini mereka membuat ruang pamer bersama yang letaknya terpisah dan berlokasi di tepi jalan masuk ke kampung Klipoh. Hanya ada satu warga yang memiliki ruang pamer sebelum ruang pamer bersama disiapkan yakni di rumah pak Poyo yang masuk dalam kelompok pengrajin modern. Gerabah hasil buatan masyarakat Klipoh khususnya milik pak Poyo ini dipamerkan di teras depan rumahnya dan sebagaian juga dipamerkan di ruang pamer bersama dengan harapan banyak pengunjung yang tertarik untuk belanja. Ruangan teras dengan luas $\pm 1.5 \mathrm{~m} \times 8 \mathrm{~m}$ cukup untuk memamerkan produk-produk gerabah. Di teras baik depan maupun samping rumah gerabah-gerabah hanya diletakkan sedemikian rupa, dan hanya produk-produk seperti lampulampu saja yang ditata diatas railing pagar dan bahkan digantung diatas. Sementara di sisi yang lain gerabah-gerabah diletakkan di dalam rak kayu yang dibuat khusus untuk display.

Produk-produk gerabah yang ditata di teras depan dengan asumsi pengunjung dapat secara langsung melihat hasil karya mereka. Namun karena keterbatasan lahan sehingga mereka hanya menggunakan teras depan atau teras belakang bersamaan dengan ruang pembuatan gerabah. Ruang pamer yang dibuat berkesan apa adanya, kurang penataan, barang-barang yang dipamerkan juga masih terbatas serta variasi produk yang kurang seringkali menjadi kendala untuk memasarkan produk.

Beberapa masyarakat yang belum punya ruang pamerpun biasanya ikut bergabung di ruang pamer bersama dan bahkan ada pula yang menggunakan gudang sebagai tempat untuk mendisplaykan produk. Lebih jauh lagi, ada pula pengrajin gerabah yang menggunakan halaman depan selain sebagai ruang pamer sekaligus juga tempat pengeringan gerabah.

Bagi pengrajin tradisional, mereka biasanya menggunakan halaman mereka untuk memamerkan produk sekaligus sebagai tempat transaksi. Pembeli sendiri biasanya langsung datang dan melihat pembuatan serta membeli produk secara langsung. Fenomena ini ternyata sangat disukai oleh masyarakat baik local maupun mancanegara. Hal ini karena mereka akan lebih memiliki experience yang dapat diceritakan ke masyarakat yang lain, sehingga merekapun dapat berperan sebagai tenaga pemasaran pariwisata. 


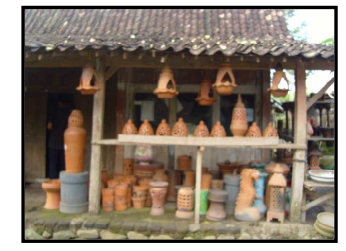

Gb. 11 Ruang Pamer Di Teras Depan

Masyarakat pengrajin melakukan beberapa proses adaptasi terhadap ruang-ruang yang mereka miliki di rumah tinggal termasuk memodifikasi ruang-ruang produksi menjadi ruang wisata. Bentuk adaptasi sosial yang dilakukan kelompok masyarakat tersebut merupakan elemen-elemen struktur sosial yang akan berinteraksi secara fungsional terhadap tatanan ruang desa yang ada disekitarnya sebagai wujud dari mekanisme kehidupan dalam memfasilitasi kebutuhan ruang wisata sekaligus mempertahankan eksistensinya. Hasil ataupun media interaksi sosial tersebut terwujud dalam bentuk sistem nilai dan simbol-simbol yang berdimensi ruang dan waktu.Sehubungan dengan kegiatan wisata, rumah pengrajin gerabah yang saat ini dibagi menjadi dua yakni rumah tinggal dan rumah produksi, keduanya disesuaikan untuk dijadikan sebagai tempat menampung kegiatan wisatawan. Dari ruang-ruang yang dibutuhkan wisatawan di ruang produksi, diketahui bahwa wisatawan menggunakan keseluruhan ruang produksi untuk dapat mengikuti semua proses pembuatan gerabah mulai dari persiapan tanah liat, proses pembuatan maupun finishing.Kondisi diatas menunjukkan bahwa kebutuhan wisatawan sangat diwarnai oleh proses pembuatan gerabah.

\section{KESIMPULAN}

Dari hasil kajian diatas dapat disimpulkan bahwa konsep pembentukan ruang-ruang wisata yang berbasis pada industri kreatif sangat tergantung pada proses produksi yang dapat dinikmati oleh wisatawan. Desa gerabag Klipoh merupakan sentra industri pembuatan gerabah tradisional maka ruang-ruang wisata yang terbentuk di Klipoh sebagai dusun wisata berdasarkan proses produksi gerabah adalah ruangruang persiapan, pembuatan gerabah, pengeringan, pembakaran, finishing, galeri. Ruang-ruang produksi tersebut digunakan selain untuk pembuatan gerabah juga untuk memfasilitasi kegiatan wisata wisatawan.

\section{DAFTAR PUSTAKA}

Ahimsa Putra, H.S. 2004. Mengembangkan Wisata Budaya dan Budaya Wisata. Yogyakarta: Puspar.

Aneka, Noor Lindawati. 2008. Dampak Pengembangan Pariwisata dan Proses Marginalisasi Masyarakat Lokal: Studi Pengembangan Obyek Wisata Pantai Gedambaan di Desa Gedambaan, Kecamatan Pulau Laut Utara, Kabupaten Kotabaru, Kalimantan Selatan. Tidak Dipublikasikan Tesis S2. Fakultas IImu Sosial UGM. Yogyakarta.

Haryadi dan B. Setiawan. 1995. Arsitektur Lingkungan dan Perilaku; Suatu Pengantar ke Teori, Metodologi dan Aplikasi. Proyek Pengembangan Pusat Studi Lingkungan Direktorat Jenderal Pendidikan Tinggi Departemen Pendidikan dan Kebudayaan Republik Indonesia

Krisyantono, Rachmat. 2006. Teknik Praktis Riset Komunikasi. Jakarta: Kencana.

Lawton, M.P. \& Nahemow, L. 1973. Ecology and adaptation in the aging process. In Eisdorfer, $C$. \& Lawton, M.P. (Eds.) Psychology of the aging process. Washington, D.C.: American Psychological Association.

Nurhadi. 1985. Urban Archaeology in Indonesia: Retrospect and Prospect. Unpublieshed Mater Thesis. University of Pennsylvania.

Rapoport, Amos. 1969. House Form and Culture. Englewood Cliffs, N. J: Prentice Hall Inc. 